\title{
SIGNIFIKANSI ILMU-ILMU AL-QUR'AN UNTUK PENGEMBANGAN ILMU DAKWAH
}

\author{
Moh. Ali Aziz*
}

\begin{abstract}
A bstract: This paper first of all believes that the concept and theories of the science of the Qur'an may be appropriated to develop the science and method of dakwah. The old method of dakwah -as it were- is concerned primarily with how the teachings of Islam and its tenets are to be propagated. The new method in the meantime -one that we prefer- should rather focus on how these teachings may be understood by the objects of the dakwah. Hence understanding is the key. The paper further holds that these two methods -old and new- are in fact interrelated and that their foundational legitimacies are to be found in the Qur'an. This paper will slightly touch on this. But a great portion of it will pay attention to the idea of the appropriation of the science of the Q ur'an by the science of dakwah, one that we believe may open up a new horizon in dakwah activities and lead to a moderate, realistic and idealistic - as opposed to liberalistic and fundamentalistform of dakwah.
\end{abstract}

Keywords: the science of the Qur'an, the science of dakwah

\section{Pendahuluan}

'U mar bin al-Khattg bercerita, “Aku pernah bertemu H isham bin $\mathrm{H}$ akim bin $\mathrm{H}$ izam yang sedang membaca surat al-Furqan semasa Rasulullah Saw. hidup. Aku mendengarkan bacaannya. Tiba-tiba, ia membaca banyak huruf yang belum pernah dibacakan oleh Rasulullah Saw. kepadaku. $\mathrm{H}$ ampir saja aku menyergapnya saat ia sedang słalat. Lalu, aku menunggunya hingga ia mengucapkan salam. Begitu ia usai mengucapkan salam, aku menarik gamis di lehernya. "Siapakah yang membacakan kepadamu surat yang telah aku dengarkan saat kamu membacanya?", kataku. la menjawab, "Rasulullah Saw. yang membacakannya kepadaku”. Aku menyanggah, "Kamu berdusta. Demi Allah, sesungguhnya, Rasulullah Saw. benar-benar telah membacakan kepadaku surat yang kamu dengar tadi". Akhirnya, aku mengajaknya pergi menghadap Rasulullah Saw. A ku berkata, "Wahai Rasulullah, sungguh aku telah mendengarkan orang ini yang membaca surat al-Furqan dengan huruf-huruf yang belum pernah Anda bacakan kepadaku, sementara Anda pernah membacakan kepadaku surat al-Furqan dengan huruf-huruf yang lain". "Lepaskanlah dia, wahai 'U mar," kata Nabi Saw. "Bacalah wahai Hisham". Di hadapan Nabi Saw., Hisham membaca surat yang telah aku dengarkan. Nabi Saw. berkata, "Begitulah surat al-Furqan diturunkan". Setelah itu, Nabi Saw. berkata kepadaku, "Bacalah, wahai 'U mar". A ku pun membaca surat al-Furqan yang pernah dibacakan Nabi Saw. kepadaku. Kata Nabi Saw., "Begitu juga surat al-Furqan diturunkan". Akhirnya, Nabi bersabda, "Sesungguhnya alQur'an telah diturunkan dengan tujuh huruf. Karenanya, bacalah apa yang mudah darinya". $H$ dith ini dinilai oleh Imam al-Tirmidhisebagai H assan S ahihh $f^{1}$

* Dosen Fakultas Dakwah IAIN Sunan Ampel Surabaya

${ }^{1}$ al-Tirmidhi>Sunan al-Tirmidhi,>Vol. IV (Beirut: Dasal-Fikr, 2005), 433-434: no. 2952. Lihat pula al-N asałi>Sunan al-Nasa'i, YVol. I, J uz II (Beirut: Dasal-Fikr, 2005), 161, no. 932; Malik bin Anas, al-M uwatt', Vol. I (Indonesia: Dar Ihyasal-Kutub al-'A rabiyyah, t.t.), 206: Bab Mała’a fi al-Qur`an. 
Dari segi bacaan al-Qur'an saja, menurut hadith di atas, Islam tidak mempersulit umatnya. Meski al-Qur'an berbahasa Arab, tidak semua orang memiliki logatyang sama saat membacanya. J ika masyarakat Arab saja memiliki ragam logat bahasa, apalagi masyarakat non-Arab yang tentu logatnya jauh lebih banyak. Dari sisi dakwah, kemudahan ini akan menarik setiap orang untuk mempelajari ajaran Islam. A kan tetapi, realitas yang mengemuka adalah kurangnya minat mempelajari Islam yang hanya disebabkan oleh kesulitan membaca al-Q ur'an dengan benar. Tidak sedikit pemuka agama menyalahkan bacaan al-Q ur'an orang lain dengan standar Ilmu Tajwid yang sempurna. Lebih dari itu, sejumlah siswa Taman Pendidikan al-Q ur'an (TPQ) tidak bisa diluluskan dengan standar yang tinggi, sehingga mereka tidak sempat mempelajari kandungan al-Qur'an yang jauh lebih bermakna dibanding bacaannya. Belum lagi efek psikologisnya bagi sang siswa. Barangkali ini yang pernah dikahawatirkan Nabi Saw. hingga menanyakannya kepada MalaikatJ ibril, "Wahai J ibril, sungguh aku diutus kepada umat yang banyak dari golongan buta huruf, di antara mereka ada nenek-nenek, kakek-kakek, anak-anak laki-laki, anak-anak perempuan, dan orang-orang yang belum bisa membaca tulisan sama sekali". J ibril menjawab, "Wahai Muhammad, sesungguhnya al-Qur'an telah diturunkan dengan tujuh huruf". ${ }^{2}$ Istilah "tujuh huruf" secara umum diartikan tujuh ragam bacaan al-Q ur'an (Qira'犯 Sab'ah), namun banyak ulama yang menolaknya, sehingga ia memunculkan ragam penafsiran, antara lain: ragam logat satu maksud, ragam logat dalam keseluruhan al-Q ur'an, ragam susunan kata satu makna, dan ragam kata satu makna. ${ }^{3}$ Apapun maknanya, tujuannya harus mempermudah umat Islam dalam membaca al-Qur'an. Demikian ini merupakan pertautan antara IImu Bacaan al-Qur'an ('Ilm al-Q ira'zh) dan Ilmu Dakwah.

Tulisan ini hendak menelusuri ilmu-ilmu al-Qur'an ('Ulum al-Qur'an) yang bisa mengembangkan Ilmu Dakwah. Istilah ilmu-ilmu al-Qur'an menunjuk pada ragam disiplin ilmu yang terkait dengan kajian al-Q ur'an. ${ }^{4}$ Keduanya masuk dalam wilayah keilmuan metodologis, bukan keilmuan substantif. Karenanya, keterkaitan keduanya perlu dikaji terlebih dahulu.

\section{Relevansi IImu Dakwah dan IImu-ilmu al-Q ur'an}

Perintis IImu Dakwah, Shaykh'Ali»Mahfuz, mengemukakan definisi dakwah Islam sebagai berikut "Menyeru manusia kepada kebajikan dan petunjuk serta menyuruh kepada kebajikan dan melarang kemunkaran agar mendapat kebahagiaan saat ini dan akan datang (hithth al-nas'ala al-khayr wa al-huda wa al-amr bi al-ma'rufwa al-nahy 'an al-munkar li yafuzu bi sa'adah al-'ajił wa al-ajil)". ${ }^{5}$ Menurut definisi ini, inti dakwah adalah seruan kepada petunjuk Islam. Seruan ini memiliki target, yaitu tercapainya kebahagiaan sejati (al-sa'adah). Kebahagiaan ini tidak dirasakan sesaat, melainkan bahagia selamanya. Iman adalah satusatunya pilar kebahagiaan sejati. Karenanya, dakwah Islam bertumpu pada upaya peningkatan iman secara terus-menerus: dari buruk menjadi baik dan dari baik menjadi lebih baik. Dakwah kepada non-muslim tidak berhenti pada perubahannya menjadi muslim, tetapi

\footnotetext{
${ }^{2}$ al-Tirmidhi>Sunan, 343: no. 2953.

${ }^{3}$ Muhammad 'Alial-S \$buni>al-Tibyan fi sUlum al-Q ur' an (Beirut: 'Akm al-Kutub, 1985), 220-222.

${ }^{4}$ Muhămmad Bakr Ismałł, Dirasatfi sUlum al-Q ur' an (Kairo: Dasal-Manar, 1991), 12.

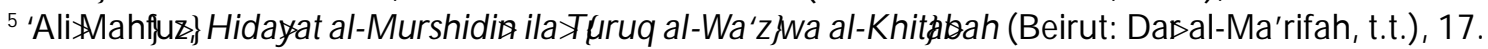


terus ditingkatkan hingga yang semula sebagai obyek dakwah atau mitra dakwah (al-mad'uw) menjadi subyek dakwah (al-da's). Proses dakwah demikian ini bermula dari pemahaman ajaran Islam yang termaktub dalam al-Qur'an dan al-Sunnah. Kedua sumber ini berupa teks yang memerlukan metode pemahaman dan penyampaian hingga relevan dengan konteks. Pesan dan metode dakwah ini dikemukakan oleh al-Q ur'an dalam surat al-Nahl ayat 125 sebagai berikut.

Serulah (manusia) kepada jalan Tuhan-mu dengan hikmah dan pelajaran yang baik dan bantahlah mereka dengan cara yang lebih baik. Sesungguhnya Tuhanmu, Dialah yang lebih mengetahui tentang siapa yang tersesat dari jalan-Nya dan Dialah yang lebih mengetahui orang-orang yang mendapat petunjuk.

Al-Hikmah dalam ayat di atas ditafsirkan dengan al-Qur'an ${ }^{6}$ sebagai pesan dakwah, sedangkan al-maw'izłh al-høsanah diartikan dengan metode dakwah. ${ }^{7}$ Kegiatan dakwah Islam dimulai dari pemahaman pesan dakwah oleh pendakwah, lalu penyampaian pesan tersebut kepada mitra dakwah (al-mad'uw). U mumnya, Ilmu Dakwah membahas proses penyampaian pesan, namun melupakan proses pemahaman pesan. Padahal, proses penyampaian pesan tergantung pada proses pemahamannya. Di antara beberapa metode pemahaman pesan dakwah diungkapkan dalam ilmu-ilmu al-Qur'an. Hal ini dapat dilihat dari keterkaitan antara beberapa bentuk dakwah dan beberapa topik yang menjadi pembahasan ilmu-ilmu al-Qur'an.

Secara garis besar, dakwah mempunyai tiga model, yaitu lisan, tulisan, dan tindakan. Model

\footnotetext{
${ }^{6}$ Ahinad Mustafa al-Maraghi>Tafsipal-Maraghi (X Beirut: Dasal-Fikr, 1953) ; J alaluddin al-Suyutij dan J alaluddin al-

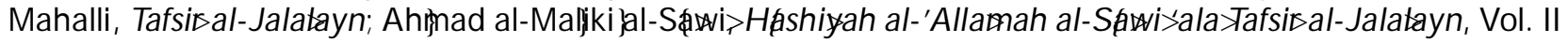
(Beirut: Dasal-Fikr, 1993), 412; A buঙ \$hir Muhłmmad bin Ya'qub al-Fairuzabadiæal-Shayrazi>Tanwipal-Miqbas

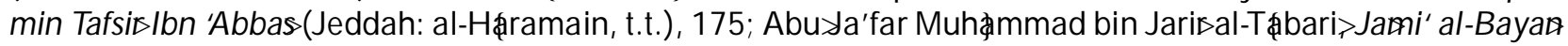
wa Ta'wilsal-Qur'an, Vol. V (Beirut: Dasal-Kutub al-'Ilmiłah, 1992), 663;. 'Abdullah bin 'Abbas, pakar tafsir di kalangan para sahabat Nabi SAW., juga menafsirkan al-hikmah dengan pemahaman atas al-Q ur'an, lihat Abu zlFidaSIbn Kathisal-H fizal-Damashqi>Tafsipal-Q ur'an al-'Azim, Vol. II (B eirut: Dasal-Fikr, 1997), 616. Penafsiran yang semakna adalah perkataan yang sempurna, yakni dalil yang menjelaskan kebenaran dan menjauhkan keraguan (al-hikmah al-maqalah al-muhkamah wahuwa al-dalilal-mudllh/li al-hæqqq al-muzih/li al-shubhah) atau argumentasi yang pasti dan berfaedah untuk aqidah yang diyakini (al-hikmah al-hyjjjah al-qat'ilyah al-mufidah li al-'aqaid al-

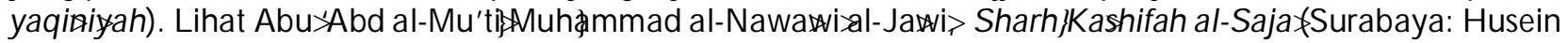
'Umar, t.t.), 469; Wahbah al-Zuhayli>al-Tafsipal-Munipfi al-'A qidah wa al-Shari'æh wa al-M anhaj, Vol. XIII (B eirut:

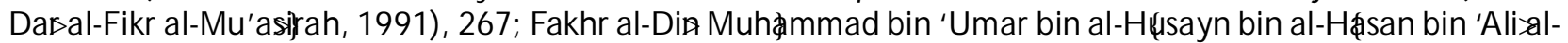
Tamimi ‘al-Bakrizal-Razi>al-Tafsipal-Kabir, Vol. X (B eirut: Dasal-Kutub al-'A rabiyah, 1990), 111; Shihab al-Diя alSayyid Mahinued al-A kusi>Ruh,al-Ma'ani fi ₹afsipal-Q ur'an al-'Azim wa al-Sab' al-M athani,>Vol. VII (Beirut: DasalKutub al-'Ilmiłah, 1994), 487; Muhłmmad J amabal-Diя al-Q asimi>M ahæsin al-Ta'wil, Vol. IV (Beirut: Dasal-Kutub al-'Ilmiłah, 1997), 422; al-'Allamah al-Sayyid Muhąmmad H ysayn al-T XII (Q um: Ismaśliyan, 1972), 371. Selain itu, al-hikmah juga berarti "yang paling utama dari segala sesuatu, baik pengetahuan maupun perbuatan. Ia bebas dari kesalahan. Al-hikmah juga diartikan sebagai sesuatu yang bila digunakan atau diperhatikan akan mendatangkan kemaslahatan dan kemudahan yang besar atau lebih besar, serta menghalangi terjadinya kerugian atau kesulitan yang besar atau lebih besar". Lihat M. Q uraish Shihab, Tafsir AlMishbah, Vol. VII (J akarta: Lentera Hati, 2002), 386.

${ }^{7}$ Pemahaman ini diambil dari beberapa penafsiran para ulama sebagai berikut: "U raian yang menyentuh hati yang mengantarkan kepada kebaikan", M. Q uraish Shihab, Tafsir al-M ishbah, Vol. VII, 387;" Ceramah yang memikat dan pelajaran yang bermanfaat, sehingga tidak ada kesamaran saat dijadikan nasehat", al-Akısi>Ruh,al-M a'ani., Vol. VII, 487; "Ungkapan yang halus dan peristiwa yang membuat mitra dakwah takut pada siksa Allah SWT", alQ asimi>M Mahæsin al-Ta’wil?, Vol. IV, 422; “Ungkapan yang indah”, Ibnu J arisal-Tabari>J ami' al-Bayan ., Vol. V, 663;" Penjelasan yang dapat melunakkan jiwa dan meluluhkan hati", al-T abałbałis al-Mizan., Vol. XII, 372;"Menyampaikan kabar yang menggembirakan dan kabar yang menakutkan serta perkataan yang lembut", alS\$wi>H ashiyah al-'Allamah al-S awi?; Vol. II, 412.
} 
lisan menggunakan media auditif (al-sam'), tulisan dengan media visual (al-absłâ), dan tindakan (al-sam' wa al-absan). Masing-masing model ini ditujukan untuk mencapai pemahaman dan kesan (al-afidah). Karena al-Qur'aß berupa teks suci yang tertulis, terbaca, dan bermakna, maka ilmu-ilmu al-Qur'an yang dikembangkan untuk Ilmu Dakwah juga diklasifikasikan menjadi tiga kelompok sasaran kajian: bacaan, tulisan, dan kandungan. Sebagai perbandingan, al-T «1 fił657$716 \mathrm{H}$.) membagi ilmu-ilmu yang berkenaan dengan al-Qur'an menjadi dua bagian, yaitu bunyi teks (lafzil) dan makna teks (ma'nawi). 'IImu Tata Bahasa dan IImu Bacaan adalah bagian dari kelompok bunyi kata, sedangkan IImu Tauhid, IImu Alam, dan IImu Sejarah merupakan bagian dari makna al-Qur'an. Klasifikasi ini terlalu umum, sehingga sulit menggambarkan al-Qur'an secara jelas. Pembagian yang lebih jelas dikemukakan oleh Quraish Shihab. Baginya, materi ilmu-ilmu al-Q ur'an terbagi menjadi empat kelompok, yaitu pengenalan terhadap al-Qur'an, kaedah-kaedah tafsir, metode-metode tafsir, dan kitab-kitab tafsir beserta mufassirnya. ${ }^{9}$ Dari keempat kelompok ini, materi pengenalan terhadap al-Qur'an lebih relevan dengan IImu Dakwah. Di antara disiplin ilmu yang terkait dengan pengenalan terhadap al-Qur'an adalah IImu Bacaan al-Q ur'an, IImu Penulisan al-Q ur'an, IImu Kemukjizatan al-Qur'an, Ilmu Keserasian Ayat-ayat al-Qur'an, IImu Kisah-kisah dalam al-Qur'an, dan sebagainya. Apabila materi pengenalan al-Qur'an dikaitkan dengan klasifikasi Bacaan, Tulisan, dan Kandungan, maka terumuskan hubungan ilmu-ilmu al-Q ur'an dengan IImu Dakwah dalam tabel sebagai berikut.

\begin{tabular}{|c|c|c|}
\hline $\begin{array}{l}\text { WILAYAH ILMU } \\
\text { DAKWAH }\end{array}$ & $\begin{array}{l}\text { OBYEK ILMU-ILMU } \\
\text { AL-QUR'AN }\end{array}$ & $\begin{array}{l}\text { ILMU-ILMU AL-QUR'AN YANG } \\
\text { DIKEMBANGKAN }\end{array}$ \\
\hline Lisan & Bacaan Teks & $\begin{array}{l}\text { 'Ilm al-Q ira'gh,'Ilm al-Bayan, 'Ilm al-Tajwid, } \\
\text { I'jazQ ira'gt al-Qur'an }\end{array}$ \\
\hline Tulisan & \begin{tabular}{|c|} 
Tulisan Teks \\
Tadwin al-M ushgdf, I'jam al-
\end{tabular} & 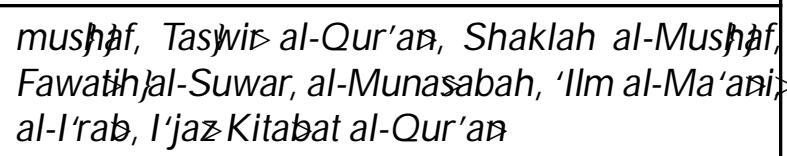 \\
\hline Tindakan & Kandungan Teks & $\begin{array}{l}\text { al-Q isæs, al-A mthal, al-Aqsam, Sabab al-Nuzul, } \\
\text { al-Makkiyah }\end{array}$ \\
\hline
\end{tabular}

\section{Tabel: Hubungan IImu-ilmu al-Q ur'an dan IImu Dakwah}

Dalam tabel di atas, terjalin hubungan metode pemahaman dari ilmu-ilmu al-Q ur'an dan metode penyampaian dari IImu Dakwah. Ketika pendakwah hendak menampilkan bacaan alQur'an, maka ia harus memahami dua hal, yaitu rahasia bacaan al-Qur'an dari ilmu-ilmu alQur'an dan pemahaman mitra dakwah atas rahasia tersebut melalui Ilmu Dakwah. Tampilan tulisan mush ga al-Qur'an akan memberikan kesan yang mendalam bagi mitra dakwah bila dipahami dengan ilmu-ilmu al-Q ur'an dan disampaikan dengan Ilmu Dakwah. Demikian pula, mitra dakwah akan melaksanakan kandungan al-Qur'an, manakala pendakwah menjadi contoh yang baik sesuai Ilmu Dakwah berdasarkan pemahaman al-Q ur'an yang tepat sesuai petunjuk ilmu-ilmu al-Qur'an.

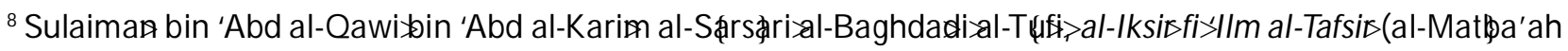
al-Namudhahliyyah, 1977), 18.

${ }^{9}$ M. Quraish Shihab, Membumikan al-Qur'an (Bandung: Mizan, 1998), 154. 
IImu Dakwah menekankan sisi konteks (pesan Islam disesuaikan dengan masyarakat), sedangkan ilmu-ilmu al-Q ur'an terfokus pada teks (masyarakat harus mengikuti pesan Islam). Paduan keduanya bisa saling melengkapi. Lebih dari itu, ilmu-ilmu al-Q ur'an bisa membatasi IImu Dakwah agar tidak terlalu realistis-pragmatis, sedangkan Ilmu Dakwah bisa menarik ilmuilmu al-Qur'an supaya tidak terlalu idealis-utopis. Sebagai contoh, teori nasikh-mansukh memperlihatkan kurang berfungsinya ayat yang telah dihapus, meski bacaannya dibiarkan. Demikian pula, teori aksiomatik-hipotetik (qat'ji-żanni) memunculkan perdebatan mengenai kejelasan kriterianya. Fungsi latar belakang turunnya ayat (sabab al-nuzul) juga dipermasalahkan: bersifat khusus ataukah umum. Bagi Ilmu Dakwah, perbedaan konsep di atas disikapi dengan mengambil pendapat yang relevan dengan kepentingan masyarakat secara umum (al-maslah jah al-'ammah). Selain itu, teori-teori ilmu al-Qur'an yang mendukung efektifitas komunikasi dakwah perlu dirumuskan dan dikembangkan.

\section{Konstruksi IImu-ilmu al-Q ur'an untuk Pengembangan IImu Dakwah}

Dalam perkembangannya, beberapa teori ilmu al-Qur'an yang telah mapan digugat kembali. Gugatan ini bermakna positif, yakni rasionalisasi al-Qur'an sebagai Kitab dari Tuhan. Para penulis ilmu-ilmu al-Qur'an masa klasik menjelaskan al-Qur'an dengan metode periwayatan. Sementara itu, masyarakat modern memerlukan penjelasan secara rasional. Oleh karena itu, hal yang wajar jika para orientalis mempertanyakan otentisitas mushigf al-Q ur'an yang beredar saat ini berasal dari Nabi Saw. Mereka mengajukan bukti adanya beberapa mush U thmani>William Montgomery Watt pun membuat permasalahan: "J ika seseorang bertanya apa jaminannya kalau al-Qur'a yang dikumpulkan pada masa kekhalifahan 'Uthman itu merupakan salinan yang benar dari wahyu persis seperti ketika pertama kali diterima dan diungkapkan Nabi Muhammad?". ${ }^{10}$ Bagi kegiatan dakwah, hal ini menjadi taruhan utama. Ketidakmampuan pendakwah memberikan jawaban berarti berdampak pada sikap skeptis mitra dakwah terhadap semua pesan dakwah. Dalam hal ini, pendakwah harus mempelajari topik Sejarah Penulisan Mush gal al-Qur'an, terutama jawaban para ulama atas kritik para orientalis di atas. Adnin Armas pernah menjawab kritik Arthur J effery. Ia menilai kesalahan J effery dari sisi kelemahan sanad (perawi 'Abbad bin Shuhayb) terkait tuduhan perubahan oleh al-H dijjaj bin Yusuf. Tuduhan mush gelain mush se 'Uthmani juga dipatahkannya dengan logika historis. ${ }^{11}$

Teori Nasikh-M ansukh (penggantian ayat) secara dogmatis tidak ada masalah. Akan tetapi kurang bisa diterima secara rasional. Teori ini didasarkan pada surat al-Baqarah ayat 105-108. Teori ini dikembangkan lebih jauh dalam aplikasi pemilihan dalil yang lebih unggul (tarjih). Secara rasional, penjelasan ini secara tidak langsung mengabaikan fungsi wahyu Allah Swt., meski terdapat pernyataan bahwa penggantinya bernilai lebih baik atau sepadan dengan yang diganti. Penjelasan ini bisa membingungkan masyarakat rasional sekaligus menjadikan mereka ragu akan kandungan al-Qur'aß. Karenanya, teori Nasikh-M ansukh perlu direkonstruksi. Menurut pendapat mayoritas ulama, penerapan Nasikh-Mansukh tidak berlaku antar ayat al-Qur'an,

${ }^{10}$ W. M ontgomery Watt, Pengantar Studi al-Qur'an, ter. Taufik Adnan Amal (J akarta: Rajawali Pers, 1991), 76-77.

${ }^{11}$ Adnin A rmas, "Mengkritisi Gugatan Arthur J effery Terhadap AI-Qur'an", J urnal Islamia (Vol. I, No. 2, Tahun 2004), 7-19. 
melainkan penggantian ajaran nabi-nabi terdahulu dengan ajaran Islam. ${ }^{12}$ Ini bisa dilihat dari keterkaitan ayat 105 dan 106. Dengan demikian, tidak ada satu pun ayat al-Q ur'an yang diganti, baik bacaan maupun hukumnya. Penjelasan ini mengandung strategi dakwah, yaitu membandingkan mutu ajaran Islam dengan ajaran-ajaran para Nabi terdahulu. Secara lebih luas, selama tidak ada dalil al-Q ur'an maupun Sunnah Nabi Saw. yang secara jelas menentang tradisi yang berkembang di masyarakat, maka ia masih ditolerir.

Kaitan dengan teori Nasikh-Mansukh adalah teori Muhkam-Mutashabih (KejelasanKesamaran). Di antara indikator Muhkam adalah Nasikh dan indikator Mutashabih adalah Mansukh. Indikator ini dikritik oleh Panggabean yang menyatakan bahwa M uhkam adalah aturan Allah Swt. dan M utashabih terkait dengan penentangan terhadap aturan tersebut. ${ }^{13}$ Meski teori

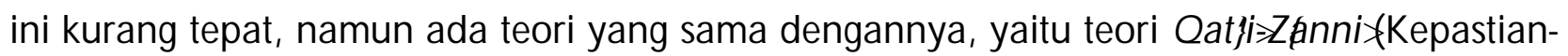
Dugaan). Teori ini terkait dengan kepastian atau dugaan makna (Q at suatu dalil maupun keberadaannya (Q at'si ¿al-Wurud-Zanni `al-Wurud). Teori ini juga masih diperdebatkan indikatornya, sehingga ia dinilai lemah. Karena tidak banyak urgensi dari kedua teori di atas, IImu Dakwah tidak mengikuti pendapat tertentu, melainkan memilih hal yang mendukung efektifitas dakwah, yakni keterpaduan antara akal dan dalil. Teks al-Q ur'a bersifat pasif dan tetap. Akal manusia yang membuatnya aktif dan bermakna. Pendakwah harus

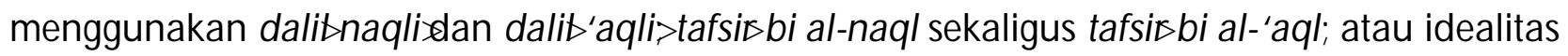
ajaran Islam dan realitas muslim.

Dalam ilmu-ilmu al-Qur'an, sisi realitas pesan al-Qur'an dikembangkan melalui latar belakang turunnya ayat (sabab al-nuzul). Porsi ayat-ayat al-Qur'an yang disertai dengan latar belakangnya sangat minim. Dilihat dari jumlah keseluruhan ayat-ayat al-Qur'an (6234 ayat), hanya sebanyak 11,46\% (menurut al-Wabidi), 11, 40\% (menurut al-Suyuki , atau 5,34\% (menurut al-Wadij'i ${ }^{14}{ }^{14}$ Meski demikian, Sabab al-Nuzul>memiliki manfaat dalam memahami makna dan arah suatu ayat. Karena universalitas al-Q ur'an, ayat-ayat 'kasuistis' ini diberlakukan

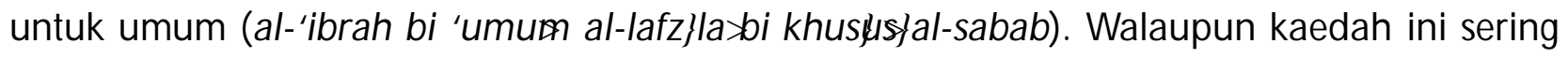
dikritik dan dimunculkan kaedah alternatif (al-'ibrah bi khusysjal-sabab la bi 'umum al-lafz), ia tetap bisa diberlakukan dengan mengambil benang merah dari kasus turunnya suatu ayat. Dalam IImu Dakwah, terdapat pesan yang berlaku umum dan khusus. Pesan dakwah yang umum sering digunakan dalam metode ceramah dan karya tulis, sedangkan pesan khusus dipakai dalam metode konseling dan pemberdayaan masyarakat. Oleh karena itu, kontribusi Sabab al-Nuzul bagi Ilmu Dakwah adalah fleksibelitas antara privat dan publik. Masing-masing berputar mengikuti hukum Allah Swt. Dalam al-Q ur'an, ada ketentuan hukum bagi manusia sebagai individu (alinsan) dan sebagai bagian dari masyarakat (al-nas). Ketentuan ini berlaku tetap, sehingga penentangnya mendapatkan siksa (adhab) dan pengamalnya memperoleh manfaat. Untuk membuktikan ketentuan ini, al-Q ur'an menampilkan kisah-kisah masyarakat terdahulu (al-qasłs)).

\footnotetext{
${ }^{12}$ Muhămmad ‘Alisal-S 100.

${ }^{13}$ Syamsu Rizal Penggabean, “Makna Muhkam dan Mutasyabih dalam al-Q ur'an”, J urnal Ulumul Qur'an (Vol. II, No. 7, Tahun 1991), 46-54.

${ }^{14}$ M. Roem Rowi, "Menimbang Signifikansi Asbab al-Nuzuldalam Pemahaman al-Qur'an”, Pidato Pengukuhan Guru Besar, Tanggal 20 Agustus 2005 di IAIN Sunan Ampel Surabaya.
} 
Kisah-kisah tersebut diutarakan dengan alur sebab-akibat, yakni apa yang dialami merupakan akibat dari perbuatannya sendiri. Karena pendakwah hidup di tengah masyarakat, materi kisahkisah dalam al-Q ur'an sangat bermanfaat baginya.

Materi lain dari ilmu-ilmu al-Q ur'an yang terkait dengan persoalan kemasyarakatan adalah konsep Makkiyah-Madaniyłah. Meski konsep ini menggunakan nama tempat, namun ia menunjuk suatu masa, yaitu sebelum hijrah Nabi Saw. (Makkiyah) dan sesudah hijrah Nabi Saw. (Madaniyah). Keduanya memiliki karakteristik yang berbeda, antara lain: besarnya porsi pesan keimanan serta pedoman dasar Sharisah dan akhlaq pada Makkiłah, sementara pesan cara pelaksanaan Sharisah pada Madaniyah; adanya kisah-kisah para Nabi dan umat-umat terdahulu di Makkiyah dan adanya bantahan atas orang-orang Ahl al-Kitab, Yahudi, dan golongan munafik di Madaniyah. ${ }^{15}$ Bagi Ilmu Dakwah, hal ini bisa dijadikan strategi dakwah, yaitu penguatan iman harus didahulukan dari pada perbaikan pengamalan. Kepada orang yang baru masuk Islam dengan iman yang masih lemah, dakwah harus diintensifkan mengenai masalah keimanan, seperti pengetahuan keesaan Allah Swt. yang dibandingkan dengan keyakinan agamaagama yang lain, terutama keyakinan yang baru saja ditinggalkannya. Selama ini, pesan keimanan kurang digalakkan dalam setiap kegiatan dakwah. Padahal, ketekunan pengamalan sangat tergantung dari kuatnya keimanan.

Pesan-pesan dakwah di atas harus disampaikan secara menarik dan sistematis. Di antara metode organisasi pesan yang ditawarkan ilmu-ilmu al-Q ur'an adalah konsep Fawatih (ayat-ayat yang menjadi pembuka setiap surat), konsep Khawatim al-Suwar (ayat-ayat yang menjadi penutup setiap surat), dan konsep al-M unasabah (keserasian dan kedekatan hubungan dan bentuk antara surat atau ayat sebelum dan sesudahnya). J ika dikaji lebih mendalam, ayat yang ditampilkan di awal surat memiliki gaya retoris yang menarik perhatian pembaca maupun pendengarnya. Ada sepuluh bentuk pembuka surat, yaitu (1) sanjungan kepada ZatAllah Swt., (2) huruf-huruf Hijaiah, (3) panggilan, (4) kalimat berita, (5) sumpah, (6) syarat, (7) kata perintah, (8) pertanyaan, (9) doa, dan (10) penjelasan sebab. Sedangkan kalimat yang menjadi penutup surat mempunyai kandungan makna yang bagus, indah, jelas, dan sempurna, sehingga ia tidak akan menyisakan kerancuan dan kesamaran jiwa manusia. ${ }^{16}$ Contoh yang menarik adalah surat al-Q ax'ah (mengetuk dengan keras hingga memekakkan telinga). Surat ini diawali dengan kata yang membentak: al-Q ax'ah!!!. Bunyi akhir pada setiap ayat juga bernada membentak, kecuali ayat 4 dan 5 yang bernada tiupan: al-mabthuth (bertebaran) dan al-manfush (dihamburhamburkan). Ada keserasian bunyi dan makna yang oleh Sayyid Quth disebut al-Tasywir, yakni seperangkat unggulan tentang gaya bahasa al-Qur'an yang mengungkapkan gambaran inderawi, persepsi, dan psikis. ${ }^{17}$ Masing-masing ayatnya memiliki hubungan: bentakan (ayat 1), pertanyaan tantangan (ayat 2-3), jawaban metaforis (ayat 4-5), inti pesan (ayat 6-9), penekanan pesan (1011). J adi, surat al-Q ari'ah ditutup dengan kata, "A pi yang panas", yakni akibat bagi orang yang tidak selamat dari hentakan yang keras. Keterkaitan surat al-Q ax' ah dengan surat sebelum dan sesudahnya adalah perjalanan dari kebangkitan dari alam barzakh (surat al-'Adiyat) menuju

${ }^{15}$ MannaSKhalibal-Q attła, Mabahith fi sUlum al-Qur'an (Beirut: Muassasah al-Risalah, 1994), 63-64.

${ }^{16}$ Muhł̧mmad bin 'Alawiæal-Maliki, Samudera Ilmu-ilmu al-Qur'an, ter. Tarmana Abdul Q osim (Bandung: 'Arasy, 2003), 219-226.

${ }_{17}$ Sayyid Quth, al-Taswipal-Fani fi al-Qur'an (Beirut: Dasal-Shuruq, t.t. ), 15. 
proses $\mathrm{H}$ ari Kiamat (surat al-Q ari'ah) hingga pertanggung-jawaban amal manusia di akherat (surat al-Takathur).

Karakteristik pesan dakwah dan gaya penyampaiannya akan bermuara pada tujuan dakwah, yaitu peningkatan iman sebagai sumber kebahagiaan. Aktivitas apapun yang dilandasi kekuatan iman akan dilaksanakan dengan senang hati dan membuahkan kebahagiaan sejati. Untuk meningkatkan iman tersebut, perlu penjelasan tentang keistimewaan ajaran Islam. Dalam ilmuilmu al-Qur'aß, keistimewaan ini diuraikan pada materi kemukjizatan al-Qur'a . Aspek kemukjizatan al-Qur'an terus berkembang, dari kemukjizatan kesasteraan bahasa al-Qur'an, keserasian tulisan, kesesuaian kandungan dengan tema sains, hingga manfaat bacaan dan tulisan untuk menyelesaikan persoalan hidup. Semua pembahasan ilmu-ilmu al-Qur'an juga mengarah pada sisi kemukjizatan al-Qur'å. Oleh karena itu, IImu Dakwah memerlukan ilmu-ilmu alQur'an. Selain sebagai metode dakwah, ia juga berfungsi untuk meyakinkan mitra dakwah tentang bukti keistimewaan pesan dakwah. Posisi ilmu-ilmu al-Q ur'an bagi IImu Dakwah dapat didasarkan pada surat al-Nahl\}ayat 125 di atas.

\section{Penutup}

Dakwah Islam dimulai dari mengamati kondisi mitra dakwah, mencari pesan dakwah, lalu memahami dan menyampaikan pesan dakwah. Agar pesan dakwah sesuai dengan kondisi mitra dakwah, perlu ilmu-ilmu al-Qur'an dan Ilmu Dakwah. Ilmu-ilmu al-Qur'an mencegah pemahaman al-Qur'a dengan pikiran yang liar. "Barangsiapa yang berkata tentang al-Qur'a tanpa ilmu, maka hendaklah ia menyiapkan tempatnya di neraka", sabda Nabi Saw. ${ }^{18}$ Pakar tafsir kenamaan, Mujahid, berkata: "Bila aku membaca bacaan Ibn Mas'ud, aku tidak menjadikan dalil hingga aku menanyakan kepada Ibn 'Abbas mengenai banyak pertanyaan yang terkait dengan alQur'an". ${ }^{19}$ Dengan menggali petunjuk al-Qur'an, pendakwah bisa menemukan kualifikasi dan tugas pendakwah, pesan dakwah, karakteristik mitra dakwah, metode dakwah, media dakwah, tujuan dakwah, dan kogistik dakwah.

\section{Daftar Rujukan}

Akusi>Shihab al-Din al-Sayyid Mahinud al-. Ruh,al-Ma'ani fi ॠafsipal-Q ur'an al-'Azim wa al-Sab' al-Mathani>VVol. VII. Beirut: Dasal-Kutub al-'Ilmizah, 1994.

Armas, Adnin. "Mengkritisi Gugatan Arthur J effery Terhadap AI-Qur'an", dalam J urnal Islamia. Vol. I, No. 2, Tahun 2004.

Ibn Kathis al-H fizal-Damashqi>A bu sal-Fadas. Tafsipal-Qur'an al-'Azim. Vol. II. Beirut: DasalFikr, 1997.

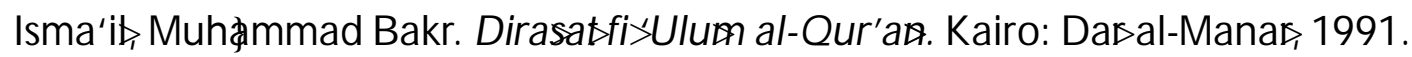

Mahffuz, Shaykh 'Ali> Hidayat al-Murshidin ila \uruq al-Wa'z'wa al-K hitabah. Beirut: Das alMa'rifah, t.t.

Malik, Anas bin. al-M uwattł'. Vol. I. Indonesia: Das Ihyasal-Kutub al-'Arabiłah, t.t.

${ }^{18} \mathrm{Al}$-Tirmidhi>S Sunan al-Tirmidhi, >Vol. IV, 439, nomor 2959.

19 Ibid., 440-441 
Małkiki, Muhł̧mmad bin 'Alawiæal-. Samudera Ilmu-ilmu al-Q ur'an. ter. Tarmana Abdul Q osim. Bandung: 'Arasy, 2003.

Maraghi>Ahmad Mustgafaral-. Tafsipal-Maraghi>B eirut: Dasal-Fikr, 1953.

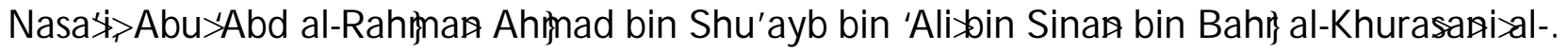

Sunan al-Nasa's al-M usamma bi al-M ujtaba>Vol. I. B eirut: Dasal-Fikr, 2005.

Nawawizal-J awi>A bu>A bd al-Mu'tiłł uhłmmmad al-. Sharh,Kashifah al-Saja. Surabaya: Husein

'Umar, t.t.

Penggabean, Syamsu Rizal. "Makna Muhkam dan Mutasyabih dalam al-Qur'an”, dalam J urnal

Ulumul Qur'an. Vol. II, No. 7, Tahun 1991.

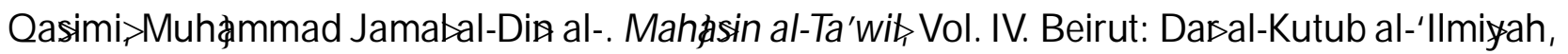
1997.

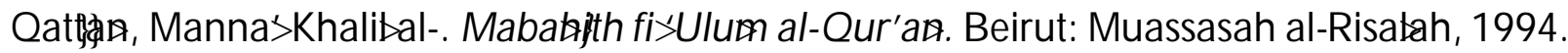

Quth, Sayyid. al-Taswwipal-Fani fi gl-Qur'an. Beirut: Dasal-Shuruq, t.t.

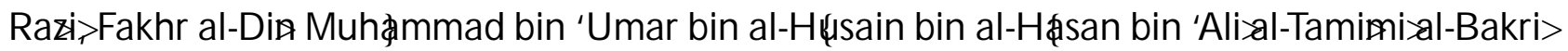

al-. al-Tafsipal-Kabir. Vol. X. Beirut: Dasal-Kutub al-'Arabiyah, 1990.

Rowi, M. Roem. "Menimbang Signifikansi Asbab al-Nuzuldalam Pemahaman al-Q ur'an", Pidato

Pengukuhan Guru Besar. Tanggal 20 Agustus 2005 di IAIN Sunan Ampel Surabaya.

S Dasal-Fikr, t.t.

- - - - - al-Tibyan fi \Ulum al-Qur' an. Beirut: 'A kim al-Kutub, 1985.

Słwi>A hinad al-Maljki jal-. H ashiyah al-'Allamah al-S awi>ala Jafsipal-J alalayn. Vol. II. Beirut: Dasal-Fikr, 1993.

Shairazi> Abu 'Abbas. J eddah: al-H tramain, t.t.

Shihab, M. Quraish. Membumikan al-Q ur'an. Bandung: Mizan, 1998.

- - - - - . Tafsir AI-Mishbah. Vol. VII. J akarta: Lentera Hati, 2002.

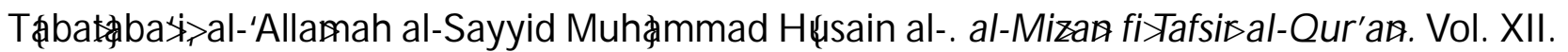

Qum: Ismasilizan, 1972.

Tabari>Abuł a'far Muhłmmad bin J arisal-. J ami' al-Bayan wa Ta'wilsal-Qur'an. Vol. V. Beirut: Dasal-Kutub al-'Ilmizah, 1992.

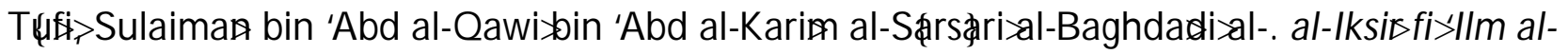

Tafsir. al-Matioa'ah al-Namudhahßiyah, 1977.

Tirmidhi>Abu>Isa»Muhł̧mmad bin 'Isałbin Sawrah al-. Sunan al-Tirmidhi>Vol. IV. Beirut: DasalFikr, 2005.

Watt, W. Montgomery. Pengantar Studi al-Qur'an. ter. Taufik Adnan Amal. J akarta: Rajawali Pers, 1991.

Zuhayli>Wahbah al-. al-Tafsipal-Munipfi al-'Aqidah wa al-Shari'æh wa al-Manhaj. Vol. XIII B eirut:

Dasal-Fikr al-Mu'asirah, 1991. 